\title{
Evaluation of various feeding programmes on growth performance, carcass and meat qualities of Thai indigenous crossbred chickens
}

\author{
P. Maliwan, S. Khempaka ${ }^{\#}$ \& W. Molee \\ School of Animal Production Technology, Institute of Agricultural Technology, \\ Suranaree University of Technology, Nakhon Ratchasima, 30000, Thailand
}

(Received 1 April 2016; Accepted 30 September 2016; First published online 8 December 2016)

Copyright resides with the authors in terms of the Creative Commons Attribution 4.0 South African Licence.
See: http://creativecommons. org/licenses/by/4.0/za/
$\begin{gathered}\text { Condition of use: The user may copy, distribute, transmit and adapt the work, but must 16ecognize the authors and the South African } \\ \text { Journal of Animal Science }\end{gathered}$

\begin{abstract}
This study was conducted to evaluate the effects of various feeding programmes on growth performance, carcass characteristics, and the meat qualities of Thai indigenous crossbred (50\%) Korat chickens to obtain suitable feeding programmes. A total of 480 one-day-old mixed-sex Korat chickens were randomly allotted to four treatments, namely FP1, FP2, FP3 and FP4, with four replicates for each treatment (30 birds per replicate) in a completely randomized design. Chickens in FP1 were fed diets with 21, 19, 17 and $15 \%$ crude protein (CP) in periods of $0-3,3-6,6-9$ and $9-13$ weeks old, respectively. Chickens in FP2 were fed diets with $21,19,17$ and $15 \% \mathrm{CP}$ in periods of $0-3,3-5,5-7$ and $7-13$ weeks old, respectively. Chickens in FP3 were fed diets with 21, 19, 17, 15 and 14\% CP in periods of $0-2,2-5,5-8,8-10$ and $10-13$ weeks old, respectively. Chickens in FP4 were fed diets with 21, 19, 17, 15 and 14\% CP in periods of $0-2$, 2-4, 4-6, 6-8 and 8-13 weeks old, respectively. At 13 weeks old, the results showed that Korat chickens fed with FP4 had a higher feed intake, but poorer feed conversion rate (FCR), protein efficiency ratio (PER), and energy efficiency ratio (EER) values than the FP1, FP2 and FP3 treatments. However, the values for bodyweight gain and blood urea nitrogen (BUN) did not differ among treatments. None of the parameters for carcass traits, meat characteristics, and meat qualities revealed differences among treatments, except for the protein content in the thigh meat of chickens fed with FP4, which had a lower value than that of the other treatments. In conclusion, FP3 represented the most beneficial results for reducing feed costs without affecting growth performance, carcass traits, nutrient composition of meat, and meat characteristics of chickens.
\end{abstract}

Keywords: carcass trait, growth, indegenous crossbred chicken, meat yield, protein level

\# Corresponding author: khampaka@sut.ac.th

\section{Introduction}

The demand for indigenous chickens in South East Asia is always increasing, although only a small portion of this demand can be met. This is the consequence of low production volume, non-uniform size and irregular quality, resulting in high production costs. Therefore, the development of indigenous chickens is unlikely to establish a reliable product, and consequently a source of income for farmers. In Thailand, several Thai indigenous crossbred (50\%) meat chicken strains have been established to resolve the problem of an insufficient supply of indigenous chickens. The Korat chicken is one of the Thai indigenous crossbred (50\%) chicken strains that are derived from breeder lines through a crossbreeding programme. This chicken strain has better growth performance than indigenous chickens, while meat qualities are similar to those of indigenous chickens. Moreover, its meat has a unique taste and texture, and low fat and high collagen levels, which are more acceptable to consumers than commercial broiler meat. However, as genetics change, the nutrient requirements need to be revised (Choprakarn \& Wongpichet, 2008; Wattanachant, 2008; Puttaraksa et al., 2012).

Feed represents approximately $60-70 \%$ of the total cost of production, especially dietary protein, which is an expensive part of feed formulation. Previous studies reported that the metabolizable energy (ME) and protein requirements of various crossbred chickens in Thailand were about $2600-3100 \mathrm{kcal}$ of ME $/ \mathrm{kg}$ and $15-21 \%$ of crude protein (CP), respectively, at 0-16 weeks old (Vorachantra \& Tancho, 1996; Chomchai et al., 1998a, b; Tangtaweewipat et al., 2000; Pingmuang et al., 2001; Tananchai et al., 2001; Polsiri, 2001; Chomchai et al., 2003). Until now, Thai farmers have preferred to feed crossbred chickens with commercial 
broiler or layer diets, since these feeds are readily available and easy to purchase. However, the nutritional content of these feeds may not be appropriate for other birds, as the excess nutrients may be excreted through the manure, resulting in environmental pollution and increased production costs (Leeson \& Summers, 2005). To solve such problems, feeding crossbred chickens on commercial diets with multi-phase feeding programmes to more precisely meet their requirements, may help to reduce feed costs without affecting growth performance.

Research was conducted on multiple-phase broiler feeding programmes, in which feeds were changed every 2-7 days (Warren \& Emmert, 2000; Pope \& Emmert, 2001; Ferket et al., 2002). The authors concluded that these programmes did not impair growth performance or carcass traits, and could reduce feed costs. Feeding programmes depend on factors such as breed, sex, age, market weight and environment (Leeson \& Summers, 2005).

Therefore, the aim of the present study was to evaluate the effects of various feeding programmes on growth performance, carcass characteristics, and meat qualities of Thai indigenous crossbred (50\%) Korat chickens to obtain a suitable feeding programme with the cheaper feed costs. It was hypothesized that a suitable feeding programme for Korat chickens could reduce feed costs without any decline in growth performance or carcass traits.

\section{Materials and Methods}

The experiment was conducted at the farm of the Suranaree University of Technology, according to the principles and guidelines approved by the Animal Care and Use Committee of the university. A total of 480 one-day-old mixed-sex Korat chickens with average initial bodyweight (BW) of $42.99 \pm 0.51 \mathrm{~g}$ were randomly allotted to 16 pens, using a completely randomized design. There were four treatments, namely FP1, FP2, FP3 and FP4, each with four replicates of 30 birds per replicate. All chicks received commercial diets, which consisted of variations in CP contents as described in Table 1. Diets were analysed in duplicate for dry matter (DM), CP, ether extract (EE), crude fibre (CF) and ash according to AOAC (1990). Chickens in FP1 were fed diets with $21 \%$ CP from 0 to 3 weeks; $19 \%$ CP from 3 to 6 weeks; $17 \%$ CP from 6 to 9 weeks; and $15 \% \mathrm{CP}$ from 9 to 13 weeks on a regular feeding programme (control). Chickens in FP2 were fed diets with $21 \%$ CP from 0 to 3 weeks; $19 \%$ CP from 3 to 5 weeks; $17 \%$ CP from 5 to 7 weeks; and 15\% CP from 7 to 13 weeks old. Chickens in FP3 were fed diets with $21 \%$ CP from 0 to 2 weeks; $19 \%$ CP from 2 to 5 weeks; $17 \%$ CP from 5 to 8 weeks; $15 \%$ CP from 8 to 10 weeks; and 14\% CP from 10 to 13 weeks. Those in FP4 were fed diets with $21 \% \mathrm{CP}$ from 0 to 2 weeks; $19 \% \mathrm{CP}$ from 2 to 4 weeks; $17 \%$ CP from 4 to 6 weeks; $15 \%$ CP from 6 to 8 weeks; and 14\% CP from 8 to 13 weeks old.

Table 1 Nutrient composition ( $\mathrm{g} / \mathrm{kg}$ ) of commercial diets (air-dried basis)

\begin{tabular}{|c|c|c|c|c|c|}
\hline \multirow{2}{*}{ Items } & \multicolumn{5}{|c|}{ Commercial diets } \\
\hline & $21 \% \mathrm{CP}$ & $19 \% \mathrm{CP}$ & $17 \% \mathrm{CP}$ & $15 \% \mathrm{CP}$ & $14 \% \mathrm{CP}$ \\
\hline Dry matter & 915.1 & 896.2 & 910.1 & 894.8 & 896.6 \\
\hline Crude protein & 212.2 & 196.3 & 173.9 & 157.8 & 142.8 \\
\hline Ash & 55.8 & 55.7 & 55.4 & 56.8 & 57.5 \\
\hline Crude fibre & 38.9 & 41.8 & 43.2 & 39.8 & 41.3 \\
\hline Ether extract & 60.5 & 71.0 & 72.8 & 49.3 & 35.1 \\
\hline Nitrogen free extract & 547.7 & 531.4 & 564.8 & 591.1 & 619.9 \\
\hline Price (US $\$ 1 / k g)$ & 0.507 & 0.499 & 0.470 & 0.413 & 0.382 \\
\hline
\end{tabular}

The birds were reared in an open-sided naturally ventilated broiler house, with a daily photoperiod of 24 hours of light. The birds were housed in floor pens $(2 \mathrm{~m} \times 2 \mathrm{~m})$ on rice husks. Each pen had one tray feeder and one manual drinker. At seven days old, the tray feeder was replaced with a round-bottomed one. All chicks were inoculated with Newcastle and Infectious Bronchitis vaccine at 7 and 21 days old, inactivated Infectious Bursal vaccine at 14 days old, and inactivated fowlpox vaccine at 35 days old. Feed and water were provided ad libitum throughout the experimental period (13 weeks). 
Bodyweight and feed intake $(\mathrm{FI})$ of each pen were recorded weekly. The data were used to calculate BW gain, FCR, feed cost per kilogram BW gain, protein efficiency ratio (PER), energy efficiency ratio (EER) and economic returns. Protein efficiency ratio was calculated as grams of weight gain per gram of protein intake, and EER was calculated as grams of weight gain $\times 100 /$ total ME intake. The production performance and feed cost data were divided into two periods (0-10 weeks old; and the entire period 0-13 weeks old) according to the market size $(1.2 \mathrm{~kg}$ and $1.8 \mathrm{~kg})$.

At the end of each experimental period, blood samples were collected from the birds' jugular vein (two birds/pen) at two hours' post feeding, and allowed to clot in polypropylene tubes for two hours at room temperature. The tubes were centrifuged at $1609 \times \mathrm{g}$ at $4^{\circ} \mathrm{C}$ for 10 minutes. The supernatant was removed and stored at $-20^{\circ} \mathrm{C}$ until analysis for BUN using Automatic Clinical Chemistry A15 Analyser according to the method of Anino \& Giese (1976).

At 10 and 13 weeks old, two birds (male and female) with live weight close to BW of 1.2 and $1.8 \mathrm{~kg}$ were selected from each pen. The birds were fasted overnight, with access to water, and slaughtered by exsanguination to determine carcass yield. After chilling for 24 hours at $4{ }^{\circ} \mathrm{C}$, the carcasses were weighed and dressed using the international cutting style (Henrickson, 1978 into breasts, fillets, thighs, thigh meat, drumsticks, drumstick meat, meat : bone ratio, and wings. Carcass yield was calculated as a percentage of live weight. Parts yields were determined as a percentage of the eviscerated carcass weight. The $\mathrm{pH}$ value was measured at 45 minutes and 24 hours post mortem in the breast muscle at a depth of $2 \mathrm{~cm}$.

Breast and thigh meat samples were collected to analyse chemical composition and meat quality attributes (water-holding capacity and shear force). Water-holding capacity was determined as drip loss and cooking loss according to the method of Honikel (1987) and Jaturasitha et al. (2008). The samples were hung on hooks in a refrigerator for 24 hours at $4{ }^{\circ} \mathrm{C}$ in an absorption pad and put into polyethylene bags. Drip loss percentage was calculated with this formula:

(weight before storage - weight after storage) / initial weight $\times 100$

The breast and thigh meat samples were measured for cooking losses. The samples were weighed and put into sealed bags. Then the samples were boiled in a water bath until an internal temperature of 80 ${ }^{\circ} \mathrm{C}$ was reached, and then cooled to room temperature and weighed again. The cooking loss percentage was calculated using this formula:

(weight before boil - weight after boil) / initial weight $\times 100$

Shear force values were determined for cooked breast and thigh muscles according to the method of Dawson et al. (1991) using a TA-XT2 texture analyser (Godalming, UK) with Warner-Bratzler shear apparatus (pretest speed $5.0 \mathrm{~mm} / \mathrm{s}$, test speed $2.0 \mathrm{~mm} / \mathrm{s}$, post test speed $10.0 \mathrm{~mm} / \mathrm{s}$, distance $30 \mathrm{~mm} / \mathrm{s}$ ). Uncooked breast and thigh muscles were analysed for moisture and protein content using the method of AOAC (1990). Cholesterol concentrations were determined in breast and thigh muscles with gas chromatography (Hewlett-Packard 6890 series GC system, USA) with a capillary column (HP 19091 A-112, $25 \mathrm{~m} \times 0.32 \mathrm{~mm} \times 0.52 \mu \mathrm{m}$ film thickness) and a flame ionization detector (Folch et al., 1957; Rowe et al., 1999).

Statistical analysis was performed by one-way ANOVA using SPSS software (SPSS, 2004; version 13.0). Each replication (pen) was used as an experimental unit. Differences among treatment means were determined by Duncan's new multiple range test. The statistical significance level for all analyses was set at $P<0.05$.

\section{Results and Discussion}

The effects of feeding programme on growth performance, PER, EER, and feed costs of Korat chickens at 10 and 13 weeks old are presented in Table 2. In the period 0-10 weeks old, the BW, FI, BW gain, PER, feed cost per weight gain of $1 \mathrm{~kg}$, and the economic parameters of chickens were not found to be significantly different between treatments $(P>0.05)$. Feed conversion rate and EER of the birds fed FP4 were poorer than the bird groups fed FP1-FP3 $(P<0.05)$. The whole period $(0-13$ weeks old $)$ showed a similar trend to that of $0-10$ weeks old. Feed intake of chickens fed FP4 increased significantly compared with control (FP1) $(P<0.05)$. Increased FI of FP4 groups resulted in poorer FCR, PER and EER $(P<0.05)$. Feeding chickens in FP4 had higher feed cost per BW gain than the other treatments $(P<0.05)$.

Overall, this study found that feeding Korat chickens with FP1, FP2 and FP3 showed similar results in growth performance, carcass traits, nutrient composition of meat, and meat characteristics (Table 2, 3, 5 and 5). However, in chickens fed with FP3 $(21,19,17,15$ and $14 \%$ CP at $0-2,2-5,5-8,8-10$ and $10-13$ weeks old) showed the most beneficial results in economic returns. This shows that FP3 could be used as a feeding 
programme for Korat chickens. Feeding chickens with FP4 resulted in increased FI compared with control. This was probably because of the protein content of this programme, which was lower than the requirements of chickens. Consequently, the birds consumed more feed to meet their needs.

Table 2 Effects of feeding programmes on growth performance, protein efficiency ratio, energy efficiency ratio and feed costs of Korat chickens at 10 and 13 weeks old

\begin{tabular}{ccccccc}
\hline \multirow{2}{*}{ Items } & \multicolumn{3}{c}{ Feeding programmes } & SEM & $P$-value \\
\cline { 2 - 5 } & FP1 & FP2 & FP3 & FP4 & \\
\hline
\end{tabular}

\section{At 10 weeks old}

\begin{tabular}{|c|c|c|c|c|c|c|}
\hline $\mathrm{FI}$ (g/bird) & 3,146 & 3,318 & 3,315 & 3,529 & 97.63 & 0.103 \\
\hline BW (g/bird) & 1,322 & 1,320 & 1,350 & 1,269 & 31.30 & 0.361 \\
\hline BW gain (g/bird) & 1,279 & 1,277 & 1,307 & 1,226 & 31.37 & 0.364 \\
\hline FCR (g feed/g BW gain) & $2.46^{b}$ & $2.60^{\mathrm{b}}$ & $2.54^{b}$ & $2.88^{a}$ & 0.05 & 0.001 \\
\hline Protein intake (g/bird) & 573 & 578 & 581 & 575 & 16.04 & 0.985 \\
\hline PER (g/g) & 2.23 & 2.21 & 2.25 & 2.13 & 0.04 & 0.240 \\
\hline ME intake (kcal/bird) & 10,410 & 10,834 & 10,882 & 11,576 & 317.57 & 0.128 \\
\hline EER (\%) & $12.28^{a}$ & $11.80^{\mathrm{a}}$ & $12.02^{\mathrm{a}}$ & $10.60^{b}$ & 0.22 & 0.001 \\
\hline BUN (mg/dL) & 0.958 & 0.813 & 0.943 & 0.938 & 0.07 & 0.482 \\
\hline Feed costs/BW gain (US $\left.\$^{1} / \mathrm{kg}\right)$ & 1.164 & 1.173 & 1.163 & 1.232 & 0.02 & 0.125 \\
\hline Feed costs (US\$/bird) & 1.488 & 1.498 & 1.518 & 1.510 & 0.04 & 0.958 \\
\hline Other costs ${ }^{2}$ (US\$/bird) & 0.804 & 0.804 & 0.804 & 0.804 & & \\
\hline Total costs (US\$/bird) & 2.292 & 2.302 & 2.322 & 2.314 & 0.04 & 0.958 \\
\hline Income ${ }^{3}$ (US\$/bird) & 2.733 & 2.729 & 2.792 & 2.623 & 0.06 & 0.360 \\
\hline Profit $^{4}$ (US\$/bird) & 0.441 & 0.427 & 0.470 & 0.309 & 0.04 & 0.096 \\
\hline \multicolumn{7}{|l|}{ At 13 weeks old } \\
\hline $\mathrm{FI}$ (g/bird) & $4,744^{b}$ & $4,981^{\mathrm{ab}}$ & $5,179^{a b}$ & $5,377^{\mathrm{a}}$ & 136.33 & 0.036 \\
\hline BW (g/bird) & 1,713 & 1,725 & 1,767 & 1,638 & 32.77 & 0.093 \\
\hline BW gain (g/bird) & 1,670 & 1,682 & 1,724 & 1,595 & 32.85 & 0.095 \\
\hline FCR (g feed/g BW gain) & $2.84^{b}$ & $2.96^{\mathrm{b}}$ & $3.00^{b}$ & $3.37^{\mathrm{a}}$ & 0.06 & $<0.001$ \\
\hline Protein intake (g/bird) & 825 & 841 & 847 & 839 & 21.40 & 0.901 \\
\hline PER (g/g) & $2.03^{\mathrm{a}}$ & $2.00^{\mathrm{a}}$ & $2.04^{\mathrm{a}}$ & $1.91^{\mathrm{b}}$ & 0.03 & 0.048 \\
\hline ME intake (kcal/bird) & $15,514^{c}$ & $16,149^{b c}$ & $17,026^{\mathrm{ab}}$ & $17,667^{\mathrm{a}}$ & 445.16 & 0.024 \\
\hline $\operatorname{EER}(\%)$ & $10.76^{\mathrm{a}}$ & $10.43^{\mathrm{ab}}$ & $10.13^{b}$ & $9.05^{\mathrm{c}}$ & 0.16 & $<0.001$ \\
\hline BUN (mg/dL) & 0.940 & 0.815 & 0.910 & 0.915 & 0.05 & 0.392 \\
\hline Feed costs/BW gain (US $\left.\$^{1} / \mathrm{kg}\right)$ & $1.287^{\mathrm{b}}$ & $1.299^{b}$ & $1.294^{\mathrm{b}}$ & $1.390^{\mathrm{a}}$ & 0.02 & 0.021 \\
\hline Feed costs (US\$/bird) & 2.148 & 2.185 & 2.231 & 2.216 & 0.06 & 0.735 \\
\hline Other costs ${ }^{2}$ (US $\$ /$ bird $)$ & 0.910 & 0.910 & 0.910 & 0.910 & & \\
\hline Total costs (US\$/bird) & 3.058 & 3.095 & 3.141 & 3.126 & 0.06 & 0.735 \\
\hline Income $^{3}$ (US\$/bird) & 3.542 & 3.567 & 3.655 & 3.387 & 0.07 & 0.093 \\
\hline Profit $^{4}$ (US\$/bird) & $0.484^{a}$ & $0.472^{\mathrm{a}}$ & $0.514^{a}$ & $0.261^{\mathrm{b}}$ & 0.04 & 0.007 \\
\hline \multicolumn{7}{|c|}{$\begin{array}{l}\text { FP: feeding programmes; FI: feed intake; BW: bodyweight; FCR: feed conversion rate; PER: protein efficiency ratio; } \\
\text { ME: metabolizable energy; EER: energy efficiency ratio; BUN: blood urea nitrogen; SEM: standard error of means } \\
\text { a, b, c Means within each row with different superscripts are significantly different }(P<0.05) \\
{ }^{1} 1 \text { US } \$=35.30 \text { Thai Baht } \\
2 \text { Other expenses include day-old chicks, vaccine, housing depreciation, labour and utility } \\
{ }^{3} \text { The selling price of Korat chicken is } 2.068 \text { US } \$ / \mathrm{kg} \\
{ }^{4} \text { Net income per kg of Korat chicken was calculated by subtracting the selling price of } 1 \mathrm{~kg} \text { chicken meat from the total } \\
\text { costs }\end{array}$} \\
\hline
\end{tabular}


Although the FI of chickens fed FP4 increased, this consumption can be limited by the gastrointestinal cavity. Birds can increase FI until they fill their gut (Ferket \& Gernat, 2006; Kamran et al., 2008) or approximately $10 \%$ of BW on a DM basis (Lopez \& Leeson, 2008). Several factors affect FI, such as size and age, environmental temperature, daylight, activity, stage of reproduction, feed palatability and availability of water (Duke, 1986).

The results for BUN showed a similar trend to that of growth performance (Table 2). The BUN values were not different among treatments $(P>0.05)$ in both periods. None of the feeding programmes resulted in significant changes in BUN values, which indicates that chickens could increase FI to reach their protein requirements. The BUN values of birds fed various feeding programmes showed similar results for protein intake and BW gain $(P>0.05)$. In general, BUN can be used as an indicator of amino acid and protein quality. Excessive or poor dietary protein would lead to increased BUN values (Kerr, 2002; Donsbough et al., 2010). However, as FI increased, the other nutrients, especially energy, would be reached beyond the birds' requirements, resulting in poorer FCR, PER, EER and high production costs (Leeson et al., 1996; Kamran et al., 2008). Over the 13 week growing period, feed costs were higher for the 10-week period by about 11$12 \%$. This is because older chickens had poorer FCR, PER and EER, which led to increased feed costs.

Table 3 Effects of feeding programmes on carcass traits of Korat chickens at 10 and 13 weeks old

\begin{tabular}{|c|c|c|c|c|c|c|}
\hline \multirow{2}{*}{ Items } & \multicolumn{4}{|c|}{ Feeding programmes } & \multirow{2}{*}{ SEM } & \multirow{2}{*}{$P$-value } \\
\hline & FP1 & FP2 & FP3 & FP4 & & \\
\hline \multicolumn{7}{|c|}{$\%$ of live weight (1.2 kg BW: 10 weeks old) } \\
\hline Eviscerated ${ }^{1}$ & 65.57 & 65.38 & 64.91 & 64.85 & 0.54 & 0.733 \\
\hline Giblets & 5.05 & 5.02 & 4.86 & 4.72 & 0.16 & 0.464 \\
\hline \multicolumn{7}{|c|}{$\%$ of eviscerated carcass (1.2 kg BW: 10 weeks old) } \\
\hline Breasts & 16.55 & 16.20 & 14.98 & 16.36 & 0.49 & 0.152 \\
\hline Fillets & 5.09 & 4.54 & 4.73 & 4.69 & 0.18 & 0.234 \\
\hline Thighs & 16.39 & 18.06 & 17.57 & 16.84 & 0.50 & 0.141 \\
\hline Thigh meat & 13.50 & 14.85 & 14.56 & 13.81 & 0.48 & 0.215 \\
\hline Drumsticks & 16.19 & 16.15 & 15.49 & 15.96 & 0.28 & 0.301 \\
\hline Drumstick meat & 12.27 & 12.16 & 11.59 & 12.16 & 0.28 & 0.361 \\
\hline Meat : bone ratio & 3.80 & 3.75 & 3.78 & 3.81 & 0.12 & 0.989 \\
\hline Wings & 13.55 & 13.75 & 13.81 & 13.93 & 0.25 & 0.756 \\
\hline Abdominal fat & 0.99 & 1.07 & 1.09 & 1.15 & 0.12 & 0.817 \\
\hline \multicolumn{7}{|c|}{$\%$ of live weight (1.8 $\mathrm{kg} \mathrm{BW:} 13$ weeks old) } \\
\hline Eviscerated ${ }^{1}$ & 68.09 & 69.29 & 68.08 & 67.65 & 0.48 & 0.142 \\
\hline Giblets & 4.46 & 4.09 & 4.63 & 4.38 & 0.18 & 0.240 \\
\hline \multicolumn{7}{|c|}{$\%$ of eviscerated carcass (1.8 kg BW: 13 weeks old) } \\
\hline Breasts & 16.13 & 15.28 & 15.70 & 16.89 & 0.72 & 0.461 \\
\hline Fillets & 5.12 & 5.33 & 5.30 & 5.69 & 0.23 & 0.397 \\
\hline Thighs & 16.64 & 17.34 & 17.45 & 17.52 & 0.60 & 0.718 \\
\hline Thigh meat & 13.85 & 14.47 & 14.43 & 14.57 & 0.51 & 0.751 \\
\hline Drumsticks & 16.52 & 15.78 & 16.46 & 16.14 & 0.39 & 0.529 \\
\hline Drumstick meat & 12.86 & 12.56 & 12.50 & 12.13 & 0.31 & 0.468 \\
\hline Meat : bone ratio & 4.19 & 4.48 & 3.87 & 3.84 & 0.19 & 0.106 \\
\hline Wings & 12.62 & 13.75 & 13.87 & 13.39 & 0.31 & 0.054 \\
\hline Abdominal fat & 1.04 & 0.94 & 1.09 & 1.27 & 0.08 & 0.087 \\
\hline
\end{tabular}


The effects of the feeding programmes on carcass characteristics are presented in Table 3 . The percentages of eviscerated carcass and giblets did not show significant differences among treatments $(P$ $<0.05)$. The test results for the percentages of breasts, fillets, drumsticks, thighs, thigh meat, drumsticks, drumstick meat, wings and abdominal fat were similar to those for the eviscerated carcasses and giblets. In addition, the meat to bone ratios did not show significant differences $(P>0.05)$. Although FP4 resulted in lower productivity than the other treatments, no significant differences were found for the carcass traits. This was probably because the birds had adjusted their $\mathrm{FI}$ to meet their requirements, and consequently no effects were found for the carcass traits or proportions of meat. These results were similar to the values reported for Thai indigenous chickens (Jaturasitha et al., 2002; Jaturasitha et al., 2008). In general, as energy intake exceeds requirements, it affects carcass traits, especially fat content. This study found that FP4 at 13 weeks old tended to increase abdominal fat, which was associated with high ME intake. This phenomenon was reported by Aletor et al. (2000), Si et al. (2001) and Sterling et al. (2002).

The results for the nutrient compositions of Korat chickens at 10 and 13 weeks old are shown in Table 4. At 10 weeks old, there were no significant differences in moisture, CP or cholesterol content in breast or thigh meats. At 13 weeks old, chickens fed FP4 showed lower protein content in thigh meats than the FP1 and FP2 $(P<0.05)$, but it was not significantly different from FP3 $(P>0.05)$. However, the other parameter measurements were not significantly different among treatments $(P>0.05)$. Many research studies have been attempted with several feeding programmes, but no detrimental effects have been found for meat quality (Brewer et al., 2006a; 2006a b; 2012). Similarly, the results of this study did not find any significant effects for moisture, protein or cholesterol content in either of the periods of the various feeding programmes, except for the protein content in the thigh meat of chickens fed FP4 (13 weeks old), which had a lower value than that of the FP1 and FP2 $(P<0.05)$. This is probably because the dietary protein in this programme may not be appropriate for birds (Scott et al., 1982; Kerr, 2002). Although the chickens were able to increase FI according to requirements, the level of feed consumption was regulated and limited by the gastrointestinal cavity. The detrimental effect of FP4 on meat protein content is also associated with the results for poorer FCR, PER and EER.

Table 4 Effects of feeding programmes on nutrient composition of Korat chickens

\begin{tabular}{ccccccc}
\hline \multirow{2}{*}{ Items } & \multicolumn{4}{c}{ Feeding programmes } & SEM & $P$-value \\
\cline { 2 - 5 } & & FP1 & FP2 & FP3 & FP4 & \\
\hline
\end{tabular}

\section{Breast meat}

Moisture (\%)
Crude protein (\%)

Thigh meat

Moisture (\%)
Crude protein $(\%)$
Cholesterol $(\mathrm{mg} / 100 \mathrm{~g})$

\section{Breast meat}

Moisture (\%)

Thigh meat

Moisture (\%)

Crude protein (\%)

Cholesterol (mg/100 g)

72.78
25.56
73.55
19.85
63.48

72.78

73.55

63.48

$1.8 \mathrm{~kg} \mathrm{BW}: 13$

$1.2 \mathrm{~kg} \mathrm{BW:} 10$ weeks old

$\begin{array}{cccccc}72.58 & 73.35 & 72.96 & 73.72 & 0.27 & 0.051 \\ 24.64 & 25.08 & 25.03 & 25.24 & 0.60 & 0.904 \\ & & & & & \\ 73.44 & 74.56 & 73.43 & 73.63 & 0.50 & 0.369 \\ 21.48^{\mathrm{a}} & 21.67^{\mathrm{a}} & 20.95^{\mathrm{ab}} & 20.35^{\mathrm{b}} & 0.27 & 0.019 \\ 66.27 & 73.99 & 69.13 & 74.12 & 4.02 & 0.461\end{array}$

\footnotetext{
FP: feeding programmes; BW: bodyweight; SEM: standard error of means
a, b Means within a row with different superscripts are significantly different $(P<0.05)$.
} 
The nutrient composition of Korat chicken meat was similar to that reported for other crossbred and indigenous chicken strains (Intarapichet et al., 2008; Puttaraksa et al., 2012). Although cholesterol content was not significant among treatments, the values were lower than for broilers by approximately $0.5-1.0$ times (Jaturasitha et al., 2002). This makes Korat chickens interesting for consumers who prefer low cholesterol meat. The effects of the feeding programmes on meat quality parameters are presented in Table 5 . The various feeding programmes showed no negative effects on $\mathrm{pH}$, drip loss, cooking loss or shear force. These values were found to be in the normal range compared with other indigenous and crossbred chicken strains (Intarapichet et al., 2008; Jaturasitha et al., 2008). Previous studies did not report detrimental effects of various feeding programmes on meat qualities (Lilly et al., 2011; Sirri \& Meluzzi, 2012; Brewer et al., 2012). This suggests that feeding programmes had no negative effects on meat qualities of Korat chickens. Their meat could therefore be an alternative choice for consumers because the meat properties are close to those of indigenous chickens and other indigenous crossbred chicken strains.

Table 5 Effects of feeding programmes on meat quality parameters of Korat chicken meat

\begin{tabular}{|c|c|c|c|c|c|c|}
\hline \multirow{2}{*}{ Items } & \multicolumn{4}{|c|}{ Feeding programmes } & \multirow{2}{*}{ SEM } & \multirow{2}{*}{$P$-value } \\
\hline & FP1 & FP2 & FP3 & FP4 & & \\
\hline
\end{tabular}

\section{Breast meat}

\begin{tabular}{|c|c|c|c|c|c|c|}
\hline $\mathrm{pH} 45$ minutes & 6.11 & 6.10 & 6.15 & 6.07 & 0.05 & 0.710 \\
\hline $\mathrm{pH} 24$ hours & 5.95 & 5.96 & 5.98 & 5.89 & 0.06 & 0.726 \\
\hline Thickness of the skin (mm) & 0.17 & 0.18 & 0.18 & 0.18 & 0.01 & 0.937 \\
\hline Drip loss (\%) & 5.24 & 6.13 & 5.60 & 5.81 & 0.37 & 0.412 \\
\hline Cooking loss (\%) & 29.02 & 27.96 & 28.15 & 28.02 & 0.70 & 0.694 \\
\hline Shear force $(\mathrm{kg})^{1}$ & 1.76 & 1.69 & 1.61 & 1.62 & 0.26 & 0.973 \\
\hline \multicolumn{7}{|l|}{ Thigh meat } \\
\hline Thickness of the skin (mm) & 0.18 & 0.20 & 0.19 & 0.21 & 0.01 & 0.344 \\
\hline Drip loss (\%) & 5.20 & 5.03 & 5.23 & 5.06 & 0.20 & 0.850 \\
\hline Cooking loss (\%) & 32.38 & 31.88 & 32.92 & 33.64 & 1.24 & 0.776 \\
\hline Shear force $(\mathrm{kg})$ & 1.79 & 1.75 & 1.70 & 1.63 & 0.14 & 0.874 \\
\hline \multicolumn{7}{|c|}{$1.8 \mathrm{~kg} \mathrm{BW:} 13$ weeks old } \\
\hline \multicolumn{7}{|l|}{ Breast meat } \\
\hline $\mathrm{pH} 45$ minutes & 6.83 & 6.91 & 6.86 & 6.91 & 0.05 & 0.590 \\
\hline $\mathrm{pH} 24$ hours & 6.82 & 6.90 & 6.79 & 6.85 & 0.04 & 0.338 \\
\hline Thickness of the skin $(\mathrm{mm})$ & 0.38 & 0.49 & 0.37 & 041 & 0.03 & 0.051 \\
\hline Drip loss (\%) & 6.63 & 7.54 & 6.66 & 6.41 & 0.55 & 0.506 \\
\hline Cooking loss (\%) & 22.63 & 24.44 & 23.03 & 25.67 & 0.75 & 0.052 \\
\hline Shear force $(\mathrm{kg})$ & 1.94 & 1.80 & 1.69 & 1.57 & 0.23 & 0.727 \\
\hline \multicolumn{7}{|l|}{ Thigh meat } \\
\hline Thickness of the skin (mm) & 0.43 & 0.50 & 0.39 & 0.45 & 0.03 & 0.160 \\
\hline Drip loss (\%) & 4.28 & 4.63 & 4.58 & 4.71 & 0.42 & 0.896 \\
\hline Cooking loss (\%) & 26.70 & 27.94 & 25.57 & 27.84 & 1.24 & 0.516 \\
\hline Shear force $(\mathrm{kg})$ & 2.02 & 1.97 & 1.83 & 1.69 & 0.28 & 0.836 \\
\hline
\end{tabular}

FP: feeding programmes; BW: bodyweight; SEM: standard error of means

${ }^{1}$ Warner-Bratzler shear force value

\section{Conclusions}

It was concluded that FP3 was the most suitable programme for crossbred $(50 \%)$ Korat chickens. It consisted of $21,19,17,15$ and $14 \%$ CP at $0-2,2-5,5-8,8-10$ and $10-13$ weeks old, respectively, without affecting growth performance, carcass traits, nutrient composition of meat, and meat characteristics. Since 
this programme was judged according to the highest profit, further applications of this research should be considered concurrently with feed costs. In addition, the future production of Korat chickens on a commercial scale needs to rationalize nutrient requirements, especially energy, proteins and limiting amino acids, such as methionine and lysine for accurate feed formula.

\section{Acknowledgements}

This research was funded by The Thailand Research Fund (TRF) No. RDG5620006 and Suranaree University of Technology (SUT).

\section{Authors' Contributions}

PM conducted the research as part of his PhD. programme in Animal Production Technology. SK and WM designed and supervised the whole study. PM and SK did the statistical analyses and wrote the paper. Finally, All authors commented on early and final versions of the manuscript.

\section{Conflict of Interest Declaration}

The authors have declared that there is no conflict of interests.

\section{References}

Aletor, V.A., Hamid, I.I., Nieb, E. \& Pfeffer, E., 2000. Low protein amino acid supplemented diets in broiler chickens: effects on performance, carcass characteristics, whole body composition and efficiencies of nutrient utilization. J. Sci. Food Agric. 80, 547-554.

Anino, J.S. \& Giese, R.W., 1976. Clinical chemistry: Principles and procedures (4th ed.). Little Brown \& Company, Boston, Ma.

AOAC., 1990. Official methods of analysis (15th ed.). Association of Official Analytical Chemists, Arlington, Va, USA.

Brewer, V.B., Emmert, J.L., Meullenet, J.-F.C. \& Owens, C.M., 2012. Small bird programmes: Effect of phase-feeding, strain, sex, and debone time on meat quality of broilers. Poult. Sci. 91, 499-504.

Brewer, V.B., Pillai, P.B., O'Connor-Dennie, T. \& Emmert, J.L., 2006a. Phase-feeding during the grower and finisher phases: Impact on growth, uniformity, and production cost. Poult. Sci. 85 (Suppl. 1), 205. (Abstract).

Brewer, V.B., Pillai, P.B., Saha, A., Owens, C.M., Meullenet, J.F.C. \& Emmet, J.L., 2006b. Phase-feeding in broilers: Impact on breast fillet dimension, cook loss, and tenderness. Poult. Sci. 85 (Suppl.1), 159. (Abstract).

Chomchai, N., Pojun, S. \& Wanasitchaiwat, V., 1998b. Effect of dietary protein and housing system on growth performance and carcass characteristics of crossbred native chicken. In: Research Annual Report 1998. Animal Nutrition Division, Department of Livestock Development, Bangkok, Thailand. pp. 95-114 (in Thai, English abstract).

Chomchai, N., Namkhun, S., Sumamal, W. \& Rojanastid, S., 1998a. Effect of dietary protein and energy levels on growth performances of crossbred native chicken. In: Research Annual Report 1998. Animal Nutrition Division, Department of Livestock Development, Bangkok, Thailand. pp. 73-94 (in Thai, English abstract).

Chomchai, N., Sumamal, W., Namkhum, S. \& Boonpukdee, W., 2003. Feed and feeding study for crossbred native chicken: 3 ) effect of dietary protein levels on growth performances and carcass characteristics of four-crossbred native chicken. In: Research Annual Report 2003. Animal Nutrition Division, Department of Livestock Development, Bangkok, Thailand. pp. 241-254 (in Thai, English abstract).

Choprakarn, K. \& Wongpichet, K., 2008. Village chicken production systems in Thailand. Proc. Poultry in the $21^{\text {st }}$ Century-avian influenza and beyond: FAO Animal Production and Health, International Poultry Conference, Bangkok, Thailand. pp. 569-582.

Dawson, P.L., Sheldon, B.W. \& Miles, J.J., 1991. Effect of aseptic processing on the texture of chicken meat. Poult. Sci. 70, 2359-2367.

Donsbough, A.L., Powell, S., Waguespack, A., Bidner, T.D. \& Southern, L.L., 2010. Uric acid, urea, and ammonia concentrations in serum and uric acid concentration in excreta as indicators of amino acid utilization in diets for broilers. Poult. Sci. 89, 287-294.

Duke, G.E., 1986. Alimentary canal: Anatomy, regulation of feeding, and motility. In: Avian Physiology. Edited by P.D. Sturkie, Springer-Verlag, New York, USA. pp. 269-288.

Ferket, P.R. \& Gernat, A.G., 2006. Factors that affect feed intake of meat birds: A review. Int. J. Poult. Sci. 5(10), 905-911.

Ferket, P.R., Van Heugten, E., Van Kempen, T.A.T.G. \& Angel, R., 2002. Nutritional strategies to reduce environmental emissions from nonruminants. J. Anim. Sci. 80(E. Suppl. 2), E168-E182. 
Folch, J., Lees, M. \& Stanley, G.H.S., 1957. A simple method for the isolation and purification of total lipids from animal tissue. J. Biol. Chem. 226, 497-509.

Henrickson, R.L., 1978. Meat, poultry and seafood technology. Prentice Hall, Englewood Cliffs, NJ, USA.

Honikel, K.O., 1987. How to measure the water-holding capacity of meat? Recommendation of a standardized method. In: Evaluation and control of meat quality in pigs. Edited by P.V. Tarrant, G. Eikelenboom, \& G. Monin, Martinus Nijhoff, The Hague, Netherlands. pp. 129-142.

Intarapichet, K., Suksombat, W. \& Maikhunthod. B., 2008. Chemical compositions, fatty acid, collagen and cholesterol contents of Thai hybrid native and broiler chicken meats. J. Poult. Sci. 45, 7-14.

Jaturasitha, S., Kayan, A. \& Wicke, M., 2008. Carcass and meat characteristics of male chickens between Thai indigenous compared with improved layer breeds and their crossbred. Arch. Tierz., Dummerstorf. 51(3), 283-294.

Jaturasitha, S., Leangwunta, V., Leotaragul, A., Phongphaew, A., Apichartsrungkoon, T., Simasathitkul, N., Vearasilp, T., Worachai, L. \& ter Meulen, U., 2002. A comparative study of Thai native chicken and broiler on productive performance, carcass and meat quality. In: Deutscher Tropentag 2002: Challenges to organic farming and sustainable land use in the tropics and subtropics. Book of Abstracts. Edited by A. Deininger, Univ. Kassel, Germany. Witzenhausen, Germany. pp. 146.

Kamran, Z., Sarwar, M., Nisa, M., Nadeem, M.A., Mahmood, S., Babar, M.E. \& Ahmed, S., 2008. Effect of low-protein diets having constant energy-to-protein ratio on performance and carcass characteristics of broiler chickens from one to thirty-five days old. Poul. Sci. 87, 468-474.

Kerr, M.G., 2002. Veterinary laboratory medicine: Clinical biochemistry and haematology. Blackwell Science Ltd., Osney Mead, Oxford, USA.

Leeson, S. \& Summers, J.D., 2005. Commercial Poultry Nutrition. Nottingham University Press, Nottingham, England.

Leeson, S., Caston, L.J. \& Summers, J.D., 1996. Broiler response to diet energy. Poul. Sci. 75, 529-535.

Lilly, R.A., Schilling, M.W., Silva, J.L., Martin, J.M. \& Corzo, A., 2011. The effects of dietary amino acid density in broiler feed on carcass characteristics and meat quality. J. Appl. Poult. Res. 20, 56-67.

Lopez, G. \& Lesson, S., 2008. Aspects of energy metabolism and energy partitioning in broiler chickens. In: Mathematical modelling in animal nutrition. Edited by J. France, \& E. Kebreab, CABI, Wallingford, United Kingdom. pp. 339-350.

Pingmuang, R., Tangtaweewipat, S., Cheva-Isarakul, B. \& Tananchai, B., 2001. Proper dietary protein and energy levels for crossbred native chickens during 6-10 weeks of age. Proc. $39^{\text {th }}$ Kasetsart University Annual Conference, Subject: Animals \& Veterinary Medicine, Kasetsart University, Bangkok, Thailand. pp. 169-177 (in Thai, English abstract).

Polsiri, M., 2001. Optimum protein and energy in diet of Southern indigenous and indigenous crossbred chicken. MS thesis. Prince of Songkla University, Songkla, Thailand.

Pope, T. \& Emmert, J.L., 2001. Phase-feeding supports maximum growth performance of broiler chicks from forty-three to seventy-one days old. Poult. Sci. 80, 345-352.

Puttaraksa, P., Molee, W. \& Khempaka, S., 2012. Meat quality of Thai indigenous chicken raised indoors or with outdoor access. J. Anim. Vet. Adv. 11(7), 975-978.

Rowe, A., Macedo, F.A.F., Visentainer, J.V., Souza, N.E. \& Matsushita, M., 1999. Muscle composition and fatty acid profile in lambs fattened in drylot or pasture. Meat Sci. 51, 283-288.

Scott, M. L., Nesheim, M.C. \& Young, R. J., 1982. Nutrition of the chicken (3rd ed.). M.L. Scott \& Associates. Ithaca, New York, USA.

Si, J., Fritts, C.A., Bournham, D.J. \& Waldroup, P.W., 2001. Relationship of dietary lysine level to the concentration of all essential amino acids in broiler diets. Poult. Sci. 80, 1472-1479.

Sirri, F. \& Meluzzi, A., 2012. Effect of sequential feeding on nitrogen excretion, productivity, and meat quality of broiler chickens. Poult. Sci. 91, 316-321.

SPSS., 2004. User's Guide, Version 13.0. SPSS Inc., Chicago, IL, USA.

Sterling, K.G., Costa, E.F., Henry, M.H., Pesti, G.M. \& Bakalli, R.I., 2002. Responses of broiler chickens to cottonseed and soybean meal-based diets at several protein levels. Poult. Sci. 81, 217-226.

Tananchai, B., Tangtaweewipat, S. \& Cheva-Isarakul, B., 2001. Energy and protein requirement of crossbred native chickens during 11-13 weeks. Proc. $39^{\text {th }}$ Kasetsart University Annual Conference, Kasetsart, Subject: Animals \& Veterinary Medicine, Kasetsart University, Bangkok, Thailand. pp. 161-168 (in Thai, English abstract).

Tangtaweewipat, S., Cheva-Isarakul, B. \& Pingmuang, R., 2000. Proper dietary protein and energy levels for growing crossbred native chickens. Proc. $38^{\text {th }}$ Kasetsart University Annual Conference, Kasetsart, Subject: Animals \& Veterinary Medicine, Kasetsart University, Bangkok, Thailand. pp. 100-113 (in Thai, English abstract). 
Vorachantra, S. \& Tancho, A., 1996. Study on the effect of protein and energy levels in 3 cross bred chickens (Suvan VI Breed). Proc. 34th Kasetsart University Annual Conference, Kasetsart, Subject: Animals \& Veterinary Medicine, Kasetsart University, Bangkok, Thailand. pp. 110-118 (in Thai, English abstract).

Warren, W.A. \& Emmert, J.L., 2000. Efficacy of phase-feeding in supporting growth performance of broiler chicks during the starter and finisher phases. Poult. Sci. 79, 764-770.

Wattanachant, S., 2008. Factors affecting the quality characteristics of Thai indigenous chicken meat. Suranaree J. Sci. Technol. 15(4), 317-322. 